\title{
THE SACRED LAKES OF THE DVINA REGION (NORTHWEST BELARUS)
}

\section{ULADZIMER LOBACH}

\begin{abstract}
The subject of research is the sacral geography of the Dvina region (in northwest Belarus), the sacred lakes situated in this region, and place-legends about vanished churches relating to these lakes. The author bases his research on the analytical method, and interprets folkloric sources, historical facts and data collected during ethnographic field trips. The main conclusion of the article attests to the fact that place-legends about a vanished church (they relate to the majority of the lakes) indicate the sacrality of these bodies of water. In the past, sacrality might have contained two closely interrelated planes: an archaic one, which originated from pre-Christian times, and that of the Early Middle Ages, related to the baptism of the people of the Duchy of Polotsk.
\end{abstract}

Key words: Belarusian Dvina region, sacral geography, sacred lakes, ancient religion, Christianisation, folklore.

During ethnographic field trips organised by researchers from Polotsk University between 1995 and 2008, a large amount of folklore data about lakes that still occupy a special place in the traditional vision of the world of the rural population was recorded. This means objects of 'sacral geography', which for the purposes of this article include elements of the natural landscape. They are related in a certain way in the collective folkloric memory to images of the afterworld, looking at it from a mythological point of view and construing an opposition to the human (profane) space. The notion 'sacral' does not always correspond with the notion 'sacred'. In Russian, it is expressed by two words, святой (holy) and священный (sacred). Therefore, a spring that is considered sacred and a bog named after the Devil can both be objects of sacral geography. The ambivalence of the term 'sacral' is determined by its original meaning: in Latin sacer means 'holy, sacral, generating a feeling of reverence', but also 'sacrificed to underworld gods, damned'.

The subject of this article is the lakes of northern Belarus that are known as 'sacred', and bodies of water to which place-legends about churches sunken in the lake are related. The scope of the study includes the entire complex of tales and beliefs related to these lakes, and the specific mythological and cultural/historical context surrounding these images and tales.

According to the linguistic, ethnographic and folkloric data available, as well as the results of field trips, 29 lakes of the type mentioned above have been identified in the Dvina region, 13 of which have names based on the word 'sacred' or derivations of it (Fig. 1). This concentration of sacral hydronyms, or lakes that are called 'sacred', is a peculiarity of the Dvina region. In the rest of Belarus, only seven lakes called 'sacred' have been found (four in the Homiel, and three in the Mahiliou region). It should also be pointed out that the concentration of lakes in the Dvina region (no more than 35 per cent of all the lakes in Belarus) is not as high as is commonly supposed. Due to popular belief, the region is often referred to as 'the land of blue lakes'. Therefore, it turns out that the reason lies in certain regional cultural peculiarities, and not in an accumulation of quantitative geographical factors. This thesis is supported by the identification of lakes called 'sacred', and related to a church that has vanished into thin air in the same area. The majority of lakes and other bodies of water to which place-legends of vanished churches are related are situated in the central part of the Dvina region, in the districts of Polotsk, Ushachy, Lepel', Beshenkovichi, Chashniki and Senno. This area corresponds with the area of Polotsk Krivichi and the distribution of their burial monuments, that is, burial mounds (Fig. 2). In the western part of the Dvina region, in the Braslav Lake District, populated predominantly by Balts, hydronyms of this kind are not known.

This peculiarity of the geographical distribution of sacred lakes makes it possible to assume that the historical precedent that became the basis for place-legends about sacred lakes was typical of the area populated by Polotsk Krivichi (the Duchy of Polotsk). Despite the archaic nature of Baltic-Slavonic lexical stock containing the root *šuenta- (Lithuanian švent-, Russian $s v e ̨ t-)$, it is, as V.N. Toporov believes, 'secondary and should be considered to be of late origin, from the period of the introduction of Christianity'. Besides, 'the Slavs were baptised earlier than the Balts; to a considerable extent, the latter learned of Christianity thanks to the Slavs' (Toporov 1998, p.22). Attention is drawn by the fact that the Latvian word svetts was also bor-

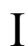

NATURAL HOLY PLACES IN ARCHAEOLOGY AND FOLKLORE IN THE BALTIC SEA REGION 


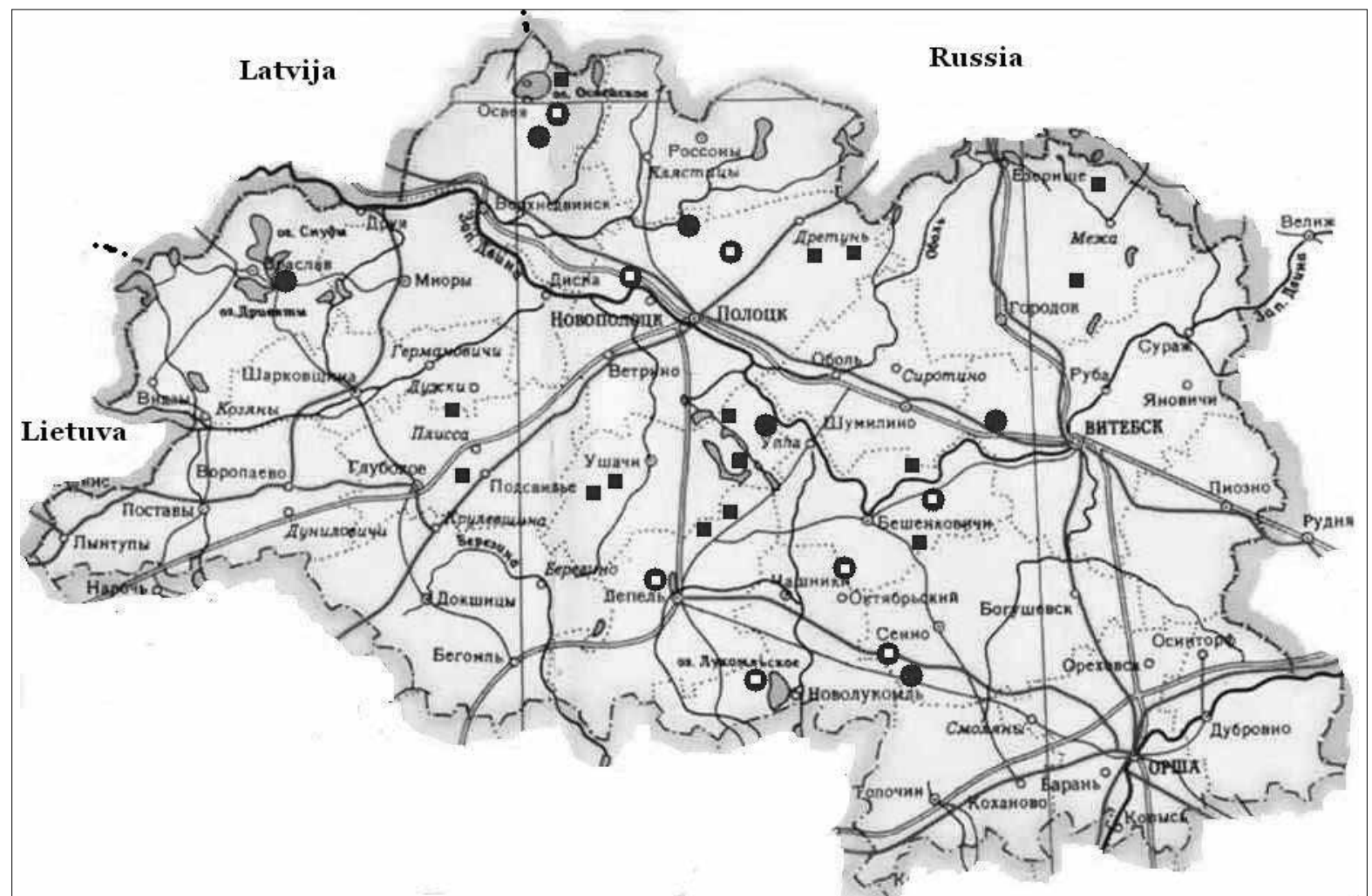

Fig. 1. The sacred lakes of the Dvina region (northwest Belarus): $\bullet$ lakes called Sacred (Святые озёра); $\mathbf{\square}$ bodies of water to which place-legends relating to a church sunken in the lake are related; $\mathbf{O}$ lakes called Sacred (Святые озёра) to which place-legends about a church sunken in the lake are related (compiled by the author).

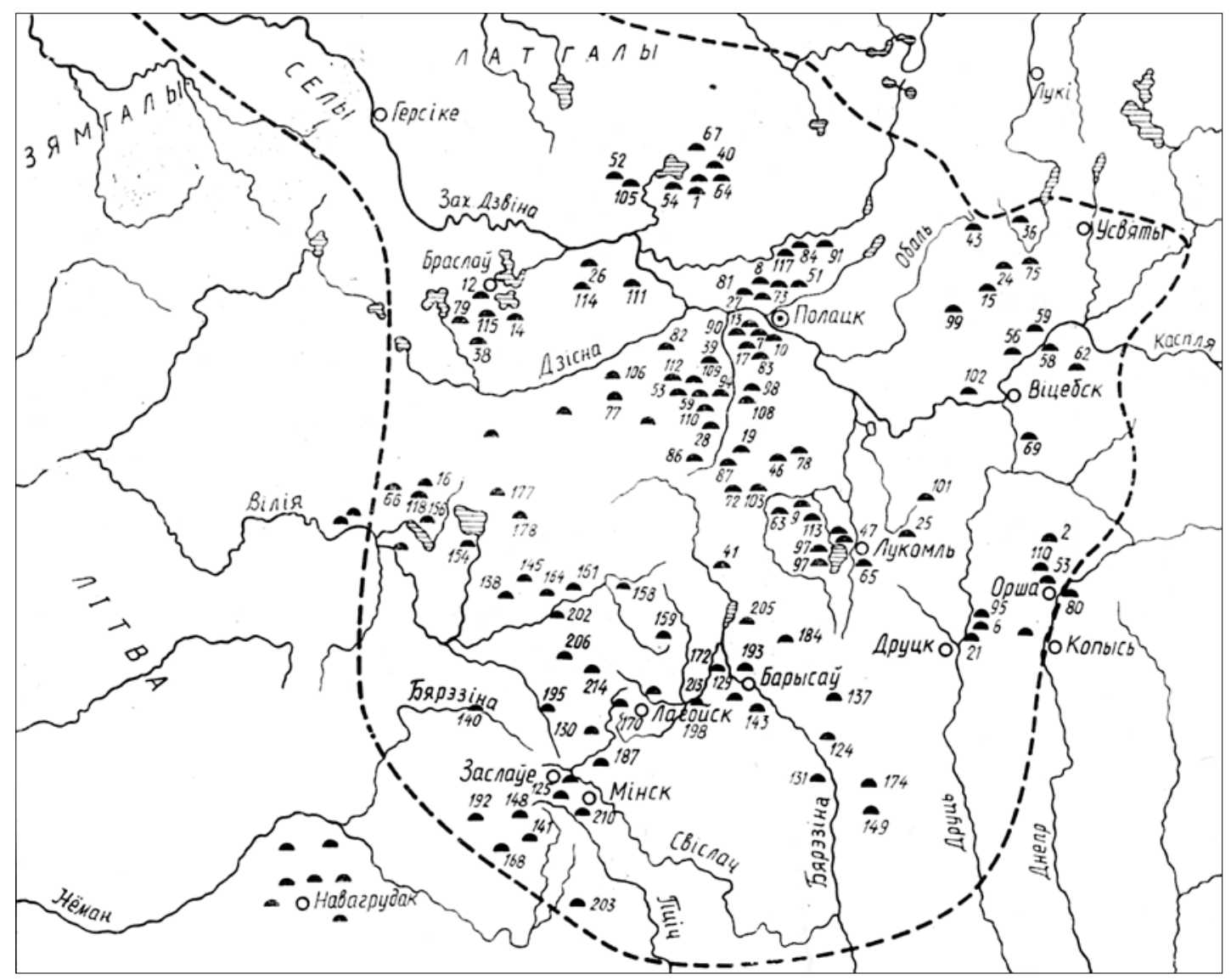

Fig. 2. A map of the Polotsk area in the tenth to 12th century, with burial mounds studied by archaeologists marked on it (Shtychov 1992, p.7, Table 1). 
rowed from the Old Russian свяm(oй) (if it was borrowed from the Baltic *svent- in the Latvian language the root would be $*_{\text {sviet-) }}$ (Toporov 1988, p.22). In this context, the distribution of sacred lakes in the Polotsk area (it is the main centre for Christianity for the entire region) and their absence on the periphery of the Duchy of Polotsk, populated by Balts, lead us to the assumption that the motif of a vanished church might have originated during the baptism of the Slavic population of the Dvina region. Later in this article, we will attempt to substantiate this thesis by analysing folkloric data.

From a folkloric point of view, the majority of sacred lakes are linked to one another by place-legends about a vanished church (or a village, or a hamlet) and its attributes (such as bells). The legends say that a lake appeared at that place. K. Anikievich, who studied the southeast part of the Dvina region, drew attention to this fact as early as the beginning of the 20th century. 'When talking about scarfed lakes, people claim that these are the locations of vanished and sunken churches. For example, old people talk about a sacred lake situated not far from the village of Simakovo, in the Ostrovets bailiwick, where many years ago there was a church dedicated to St John the Baptist. When the church vanished, a lake appeared in its place. In general, it is highly probable that a long time ago there used to be churches standing close to these locations, and that in the course of time they disappeared' (Anikievich 1907, p.39).

An analysis of folklore shows us that the cause of the unexpected disappearance of a church was believed to be the violation of certain religious and ethical norms, and a punishment imposed by higher powers (God) on humans. For instance, a place-legend about a sacred lake next to the village of Selishche, in the Verkhnedvinsk district, runs as follows: 'People say that there had been no lake there earlier; there was a church standing there. People were angry with each other, or not everybody went to church regularly; therefore, the church, with the people inside it, vanished underground. Lake Sacred appeared in its place' (Ад людзей чула, ито раней возера не было, а на яго месиь была изарква. А людзі то лі ругаліся, то лі дрэнна хадзілі уц изаркву, патаму яна з людзьмі правалілася пад зямлю. А на гэтылм месиы абразавалася Сьвятое азяро) (AGFF R-95).

In some cases, place-legends mention human sins only indirectly. For example, the origin of Lake Sacred next to the village of Borovyye, in the Chashniki district (Fig. 3), is related to the corvée on Sundays: 'In times gone by, old people would say that there used to be a church there. People from our village, from Borovyye, would go there on their way to work. There was no landlord in Mihalov, only a housekeeper. The serfs went to rake hay one Sunday. On their way, they prayed in the church and then went on to Mihalov. When they came back, the church was not there. They used to walk to the fields along the same path every Sunday. Old people would say that the church used to be in the middle of the lake. And that all that was left was water' (Калi што старыл гаварылі. Там была изэккай. I у гэту цэркаў хадзілі людзі з нашай дзярэўні, з Баравых. I яны на работу ішлі, а хадзілі... Ну, ён быў ня пан у Міхалове, а панскі эканом. I вот яны хадзілі туды сена грэсьиі, ну, а гэта было васкрасеньня. Вот яны туды ішлі, людзі, зайшлі у иэркаў, памаліліся i пайшлі у Міхалова. А тады ішлі назад, а иэрквь угжо нет. Яны кажны раз хадзілі туды ў васкрасенне на работу. Старыя людзі гаварылі, ито гэтая иэрква стаяла пасерадзіне гэтага возера. A тады стала кругом яе вада і изэркаў) (AGFF Ch-08).

The unexpected disappearance of a church and the appearance of a lake in its place is a consequence of words of damnation addressed to the sacred place. This can also be called a sin and blasphemy. A place-legend of this kind has been recorded. It tells about Lake Sviatets, next to the village of Mikulino, in the Polotsk district (Fig. 4): 'An old woman told about a church when she was 105 years old and I was 15 . She knew this place-legend. A church used to stand there. A woman came up, stumbled and fell over. She said: "Damn you!" and the church disappeared under the ground. It was in the old days that my grandmother told me about it. There were even planks floating in the lake a long time ago. When someone approaches the lake at noon, he or she hears sounds, like the ringing of bells' (Ну вот, гэта бабка расказвала пра изэркву, ёй 105 год было, када мне пятнаџџцац̧ь. Гэта яна ујжо чула прэданьне эта. Стаяла иээркаў тут. Бабка ішла якая-та у иээркаў $i$, гаворыць, што зачапілася там i павалілася. Гаворыць: "Каб ты правалілася!" I вродзі бы иээркаў гэта правалілася. Ну і раньшэ вось, гэта ууё старушка расказвала, раньшэ дажа доскі плавалі якія-та па возеру. I вось ужо як падойдуць, так у вабед, - гул такі, як званы) (AGFF P-08) (Fig. 4).

A story about Lake Sacred situated next to the village of Shchepernya, in the Polotsk district, which has been recorded only once, says that God consecrated the existing lake in a special way: 'Old people say (we would ask such questions, too) that we used to ask when we were small: "Why is this lake called Lake Sacred?" The answer would be: "The Good Lord blessed the lake with the sign of the cross, and some item of the Lord fell into the water." The old women would say that the Lord threw something into the lake. He threw

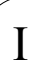

NATURAL HOLY PLACES IN ARCHAEOLOGY AND FOLKLORE IN THE BALTIC SEA REGION 
it into the water and blessed the lake. That's why this lake is called Lake Sacred. And it is deep! You cannot swim in it, you cannot do anything ... There are fish in it, but you cannot catch them, even if you try. It's a very, very deep lake, they say. That's how this Lake Sacred came into being!" (Гавораць старынныя людзі, мы тожа так спрашывалі. Малья былі, кажам: "А чаго гэта яго называюиь Святое азяро?» Янь гавораць: «Божанька яго пераксиіў $i$, - гавораџь, - туды зваліў ад Божанькі нешта. Туды, у гэнае азяро». Гэта яны самі старухі падсказывалі, што Божанька, гавораць, туды нешта скідаваў. Да, скінуў $i$ вот гэта вада стала свяниона. I вот гавораиьь, ито і абразавалася Святое азяро! І яно топкае. Ў яго ияяпер няльзя туды лезиі, нельзя нічога... ну там ёсиь рыба, но але там, калі $і$ будзе рыбіна, то не паймаеш. Там дужа-дужа топкае, яно абразавалася, гавораць, там ужо на топкасиі. Вот ано за тое абразавалася эта Святое азяро!) (AGFF P-05).

Nevertheless, it should be admitted that in most instances the folkloric memory no longer records the appearance of sacred lakes on the site of a church, but states the very mythical precedent only. 'In the Lepel' region there were stories that Lake Sacred was called sacred because a church disappeared under the ground in a place where there is now a lake. You should not swim there, or else you will definitely drown. They say the lake gets very deep very close to the shore. And, they say, bells ring on the bottom of the lake at Easter' (У Лепілі во, гаварылі, ито Сьвятое возера называецица сьвятое, ито вот правалілася цуарква там, у тое азяро. Гэта есьлі купациа - нельзя там, што уссе раўно туды утопішся. Там ад берага гльбока зразу, кажуиьь. I урродзе гаварылі, ито уу Паску там чуваць, ито званы звоняиьь, у тыл азяры) (AGFF L-06). A story about Lake Tserkovishche next to the village of Trudy, in the Polotsk district, goes like this: 'Yes, there was a lake at the foot of the hill. A church disappeared under the ground there. They say a man was fishing there. He caught a bell: "I'll be able to buy a lot of tobacco with this bell." But the bell slipped out of his hands, and a clear lake appeared. Whatever you throw into the water you can see, but there is no bottom' (Да, пад гарой-азяро. Правалілася иэрква. Адзін чалавек лавіў рыбу. Гаварылі так. Паймай звон. Ну і гаворыць: "Я иялер табакі накупляю за гэты звон”. А звон вылецеу з рук. Абразавалася зоркае азярко, там шуміну ўкінь - яна відаџь. І дна нет) (AGFF P-05).

It sometimes happens that in regions where people of different religions live, a Catholic church is mentioned in sites of this kind: 'I've heard that there used to be a church there. There is an islet in the lake. Do you know that there is a large lake between Mnyut and Valets? They say that people find bricks there: a church disappeared under the ground, and a lake appeared in its place. There wasn't lake there before, but then the church disappeared under the ground, and now there is an islet in that place' (Гэта я чула, што касиёл нібы быў. І там ёсиь остраў, на возеры. Вот между Мнютам тылм і Вяльцом возера бальшое, знаеце? Hу і гавораць, ито там і кірпічь, ито там праваліўся нейкі касиёл і вот стала возера. Там не было возера, гэта самае, праваліўся касиёл $і$ вот там такі востраў ёсиь) (AGFF G-07).

Place-legends about churches and settlements that disappeared under the ground are typical not only of the Dvina region but also of the ethnic Belarusian area in general. As Alexander Panchenko, a researcher into Russian sacral geography, notes: 'Stories of sunken towns, monasteries, churches, and so on, are widespread throughout Europe, and more often than not they are related to stories of blasphemy, a punishment for sins, or, vice versa, a miraculous escape from enemies and assailants. The plot develops in the form of a legend, a novelistic tale or a place-legend adapted to a certain object of the landscape (Panchenko 1998, pp.141-142).

When analysing such legend-related topography in Belarus, the archaeologist Edvard Zajkovskij drew attention to the fact that place-legends about a vanished church are related to three types of landscape objects: hill-forts, hills of natural origin, and lakes (Zajkovskij 2006, pp.165-166). He also believes that 'a certain number of place-legends about a church that disappeared under the water or the ground are a remote repercussion of a pagan shrine that actually existed there,' although he does not indicate any instruments for the verification of the place-legends that tell about shrines from pre-Christian times (Zajkovskij 2006, pp.164-165).

When characterising the structural scheme of placelegends about a sunken (vanished) church, A. Panchenko points out that it can be described in the following way: the sacred locus becomes a place where a conflict (due to blasphemy, the wrath of God, an onslaught by assailants and other kinds) takes place against the background of sacred/non-sacred and own/alien oppositions. As a result of the conflict, the church disappears under the ground, or it sinks, that is, it goes under the ground beyond the boundaries of the world of the living. Sometimes the disappearance of the church underground is replaced by its destruction (Panchenko 1998, p.148). However, he does not make any attempt to reconstruct the historical realities that formed the basis for such a plot. 
One approach to the study of the origin of place-legends about the sudden disappearance of churches and settlements emphasises geomorphological factors. According to L. Salavej, one of the reasons why such a folkloric plot came into existence is the fact that 'in the past, karstic phenomena would occur in our area: lakes would overflow and, quite often, flood places. This would have an impact on the fate of the settlements there' (Salavej 2006, p.535).

If this explanation of the extremely widespread folkloric motive is accepted, we should consider the fact that Belarus (and Europe in general) was still an area of active geological cataclysms in the course of recent millennia. Furthermore, the objects of the cultural landscape which have survived to this day virtually unchanged, that is, hill-forts, contradict this explanation.

Another explanation that 'hill-forts called churches (Церковище) can be related to the pagan cult' (Duchys 1993, p.9) raises doubts, too. If this is the case, then formally any hill-fort dating from the Iron Age might have had a sacral place intended for the religious needs of the community living there. However, in that case (if we admit that there is a direct cultural link between the archaeological cultures of the Iron Age and the population of Belarus of the feudal period, including their collective memory), place-legends about a church that sank into the ground should apply to most hillforts, if not to all of them. Furthermore, in locations where the folkloric memory has preserved memories of a cult object of pre-Christian times, place-legends about a sunken church are not known (cf. Legendy 2005, pp.239, 278, 283).

When analysing folkloric plots (they accompany not only archaeological monuments, but natural objects as well, such as lakes and hills) we can see that the main cause of the disappearance of a settlement or a church is a conflict related to a violation of the norms of the world-view (moral/ethical, religious, and so on). In other words, it is a conflict between a group (the human) and the god (the church). However, in the folkloric tradition of the 19th and 20th centuries, the god is, without doubt, Christian. This fact is strongly supported by the place-legend about the origin of the lake situated next to the village of Novosiolki, in the Dzerzhinsky district. The lake appeared in the site of a village, the people of which were reluctant to accept the new religion: 'An old man drew aside those who would not go to pray in the church, and drove a stick into the ground ... A strong young man stepped forward from the crowd and pulled out the stick ... A strong jet of water shot out from the small pit and flooded the village and its people. Only those inside the church survived' (Tыхx, што не пайшлі маліцица, дзядок адвёу крышку далей $і$ ўваткнуў у зямлю кіёк... 3 натоўпу выйшаў адзін здаровы маладзец $і$ вырваў кіёк..., з гэтай ямкі хльнуула) (Legendy 2005, p.410).

In this case, the transfer of people who do not accept or follow Christianity to the lower sphere of the world might reflect the clash between two cultural and religious traditions (paganism and Christianity). The official victory of Christianity does not annihilate paganism, but pushes it into a certain cultural 'underground'.

It is quite probable that a historic act of baptism of the population of a location and alleged conflicts served as the precedent for a folkloric plot. In this respect, information recorded on the basis of a story told by an old local resident about Lake Sacred situated next to the village of Strelka seems relevant. The place-legend tells of a sunken church, too: 'Lake Sacred is called that because pagans were baptised in it. That is what my grandfather told me' (Святое азяро назывеция так, бо ў ім храсьиілі язычнікаў. Мне так яшчэ дзед казаў) (AGFF R-95). In place-legends of this type, the image of a church equals unification, and embodies the spiritual unity and the identity of a group of people. The fact that in a number of place-legends the main point is the disappearance of an entire group of people who had gathered in the church to pray is worth attention. For instance, in the place-legend about Lake Bottomless next to the village of Gorodilovichi, in the Verkhnedvinsk district, this theme is stressed: 'People gathered in the church to pray on Easter night. A girl went there, too. At night, someone knocked on the window of her mother's house and told her to go and bring her daughter back from the church. She did as she was told, while the rest sank into the ground together with the church. A lake appeared there. The mother and daughter survived because they were sinless' (Сабраліся людзі на службу уц иаркву на угсю ноч (Вялікдзень). І дачка адной маткі тожа пайшла. А ноччу той матке нехта ў акно пастукаў $і$ сказай, каб ішла і забрала сваю дачку з царквыл. Ну яна так i зрабіла, а астальныя разам з иэрквай праваліліся. Возера стала. А матка з дачкой спаслісь, ито бязгрэшныя былі) (AGFF Dr-03).

It is symbolic that, as people understand it, a church or a settlement with its people does not disappear for good, but is transferred to another world and goes on with life there. This is shown by human voices or the ringing of church bells, which can be heard at a time that bears a certain ritual significance (during holidays) when the boundary between this world and that one becomes absolutely insignificant.

This opinion does not imply that a location for the act of baptism and a legendary church cannot coincide with

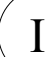

NATURAL HOLY PLACES IN ARCHAEOLOGY AND FOLKLORE IN THE BALTIC SEA REGION 
a natural holy place of pre-Christian times, rather the opposite. It should be pointed out that during archaeological research, a pagan sanctuary dating back to the ninth or the tenth century was discovered precisely on the shore of Lake Sacred in the Rogachov district in the Homiel region (Kuza, Solovjov 1972, pp.43-45).

The concentration of objects of sacral geography around certain sacred lakes is so high that it makes us think that they enjoyed a religious status in preChristian times. For instance, not far from Lake Sacred next to the village of Selishche, in the Verkhnedvinsk district, there used to be a Mount Sacred (destroyed in the 1970s) and a spring that was considered sacred; whereas the neighbouring lake called Strelkovskoye, just like the River Uzhitsa that flows out of the lake, enjoys a special status in the eyes of old residents of the location: 'There are two sacred lakes. Lake Strelkovskoye is sacred, too. The River Uzhitsa flows out of it. It is called that because, they say, there used to be a forest called Sacred in the place where the lake is now. The forest sank into the ground, and grass-snakes fled from it. There were so many grass-snakes that the River Uzhitsa appeared. In Lake Sacred situated beyond Strelka, the water has healing properties. Whoever drinks the water is healed' (Але Святых азёр два. Стралкоўскае - тожа Сьвятое. 3 яго иячот рака Вужыца. А называещиа так таму, што калі-та на месиы, дзе зараз возера, рос лес-яго звалі Святым. $\ddot{Е}$ праваліўся пад землю. А вужы сталі уияякаиь 3 яго. Іх было так многа, што абразавалась рака Вужыца. А у Святым возеры, якое за Стралкамі, вада лячебная. Хто п'ещь - выздаравіщь) (AGFF R-95).

In the forest next to Lake Sacred (by the village of Borovyye, in the Chashniki district) there is a sacred spring called Jesus (Изус), a stone under which French soldiers allegedly hid their riches, a stone with the print of an apostle's foot (the stone has not survived), and two groups of Krinichi barrows dating from the tenth or 11th century; whereas on the shore of the lake there is a hill called Horodishcha (Городище) (not yet studied by archaeologists) and a place called Balgan (Балган). Balgan, they say, was the place where merchants would gather and trade. There are sacred springs next to Lake Sviatets (in the Polotsk district), Zhabinak (in the Lepel' district), Vochka (in the Shumilinsk district) and Lake Sacred (in the Chashniki district) too.

Special properties of the water of certain lakes, in which, as the stories go, churches sank, and the physical peculiarities of those bodies of water deserve special attention. The majority of recorded stories stress the unusual depth of these lakes (they are considered bottomless) and talk about underground rivers: "'Lake
Bottomless." Where have you been, where did you pasture your cows? At Lake Bottomless, this is what they say. Yes, there used to be a church there. My mother or grandmother told me so. A man was reading the Gospel there. An old man came asking for shelter for the night, and then read the Gospel. And then something happened. A child began to cry, or something like that. And the church sank into the ground, and only the table with the Gospel on it stayed floating on the surface of the water. Who knows, it is a grandmother's fairy tale. The lake is bottomless. It is connected to Lake Asveуа' („Бяздэннае азерка“. А дзе ты быў, дзе каровы хадзілі? - Ля Бяздэннага азерка, - во такая гаворка. Ага, там цэрква стаяла. Матка ці баба гаварылі. А тады тамака мужык адзін Евангельлю чытаў. Дзядзька зайшоўся начаваць і чытаў Евангеллю. А тады, што ета нешта случылася. Рабенак плакаў, ну, нешта такое было. I гэта зразу правалілася гэта цэрква. Плаваў толькі стол, на тым возеры, дзе Евангельле ляжаў. Хто яго ведае, ну, можа, басню баба расказвала. Там нет дна. Там ці яно саедзіняецца $з$ гэтым Асвейскім, можа, як з возерам“ (AGFF Dr-03).

In this world-view, the immense depth of a lake, or the absence of a bottom altogether, means a special status for the lake and, accordingly, a number of prohibitions or taboo-type beliefs are based on it. As a rule, it is prohibited to swim in such lakes, because a human faces a deadly danger: 'There [in Lake Leshava], as some old fishermen say, springs appear in the middle. It looks as if something is swirling around, or chasing someone there. It can catch and pull you down, then it is the end' (Там [озеро Лешава], гавораиь некатарыя старыя рыбакі, што там такія ключы паяулляючияа напасярод. Тамнешта, як круиіць што, якхватаіиь. Да, й можыць схваиіиь, закруиіць - $і$ ўсё) (SET).

On one hand, people believe that the water such as that in Lake Sviatets mentioned earlier is dead. 'The lake seems to be bottomless. There are no fish there. My son caught some crucian carp in a pond and put them in the lake. He let the fish loose in the lake. One side of the lake is deep, and the other is shallow. He says he came the next day (he had put a bucketful of fish in the lake), and all the crucian carp were floating in the lake bottom-side-up. There are no fish, only some large beetles. There are no frogs, no fish, nothing. In the winter the lake would freeze. People tied some poles together and tried to measure the depth, but in vain. There are no live creatures in the lake. Thank God, no one has drowned there, but they say even dogs never go into the lake' (Гэта возера, як бяздоннае. У ім рыбы аніякай ня водзічиа. Вот дажа мой сын, карасёу налавілі у сажалкі і запускалі туды. Во запусиілі, з гэтай стораны яно топкае, а аттуда - яно нятопкае. Падашлі, і вот, гаворуць, назаўтра прышлі, 
вот ён вядро карасёў туды выліў. Назаўтра прышлі, а там гэтыл карасі, вот усе ўверх брушкамі плаваюиь. Рыбы нет, толькі жукі такія бальшыя плаваюиь. Ні лягушак, ні рыбы - нічога нет. І зімой там каток, і тады звязвалі жэрдзей, і піхалі, $і$ каниа нет.Там ніхто не жывецьь. Людзі там не тапіліся, слава Богу, але, кажуиьь, і сабакі туды ніколі не бегаюиь) (AGFF P-05).

On the other hand, the water of most lakes, the geomorphological properties of which are similar (the lakes are deep), possesses a vitalising and extraordinary power. For instance, the waters in Lake Sacred by the village of Selishche (in the Verkhnedvinsk district) and Lake Leshava (in the Ushachy district) possess healing properties. They were used for the treatment of eye diseases. One characteristic of the water of Lake Sacred next to the village of Slobodka (in the Chashniki district) (Fig. 5 ) is, as local people say, the extraordinary and lifesaving lightness, thanks to which not a single person has drowned in it. 'Elderly people say that there used to be a church, which then sank. That is why the lake is called Sacred. If someone is swimming and there's a danger of drowning, the person does not drown. Sometimes people would say that bells could be heard ringing in the lake; the lake is very deep' (Гаварылі старыя людзі, ито там стаяла иээква і яна там утанула. Таму і называециа Святое возера. Тут, калі купаусся хтосьиі і прыхадзілася тануцьь, але ніхто не тануу. Нікада і гэта ж бальшое возера як ізвесна. Інагада гаварылі, што нехта сльишау, як званы звонюиь там. Возера гэта вельмі гльбокае) (AGFF Ch-08).

Another fact, in our opinion, is no accident either: the majority of the sacred lakes of the Dvina region are small, circular bodies of water, and traditionally the circle is 'one of the most important mythopoetical symbols that reflect the cyclical notion of time (life, the year) and the structural notion of space (space is divided into "own" and "alien", whereas the circle serves as the boundary of an enclosed and protected space) (Belova 2004, p.11). This is important, especially when one bears in mind that old natural holy places and sanctuaries 'were usually circular in shape', whereas the majority of cult places were 'objects of natural origin' (Rusanova, Timoschchuk 1993, p.9). Most likely, when determining a site for teophany, the human of pre-Christian times would instinctively consider a small round lake, a circle. In the mythopoetical mind, the same lake would be perceived as an eye (око) and a window (окно) to the afterlife, and a point of connection with it. A number of lakes in the Dvina region are very small and, as a rule, circular in shape, and people believe that they are very deep or even bottomless. They are given corresponding names, for instance: Акно, Акенца (in the Polotsk district), Акнистае (in the Miory district), Вокнишча (in the Haradok district). The lake called Вочка in the Shumilinsk district, where, as place-legends go, a church sank, can be attributed to the same group.

It should be stressed that studies of sacred lakes of the Dvina region are still in their early stages. This means that factual data is collected first, and attempts are made to reflect on them. There are promising studies of bodies of water singled out in the folkloric memory ahead: the definition of their status on the mythopoetical map of the world, and ritual functions in the diachronic and synchronic cultural cross-section. The above-mentioned lakes require further studies of a complex and multi-disciplinary nature, based on modern archaeological, ethnographical, ethno-linguistic and geological (geodetic) methods, and best experience. We can draw a few preliminary conclusions to summarise this article:

1. Place-legends of churches that disappeared from the surface of the ground quite unexpectedly (sank in water or into the ground) occupy a special place in the mythological landscape of the Dvina region. Many of these place-legends are related to lakes found in the central part of the region, which in a historical perspective coincides with the nucleus of the Polotsk area in the tenth to the 11th centuries, and the area where the burial mounds of Polotsk Krivichi are concentrated.

2. An analysis of folkloric data leads us to the conclusion that in the 19th and 20th centuries the subject of a vanished church or settlement was related to the violation of moral/ethical and religious norms, and reflects a clash between two cultural/religious systems, paganism and Christianity. Place-legends related to actual landscape elements might reflect the historical act of baptism of the population of a certain micro-region.

3. The high symbolic status of sacred lakes in the world-view of the present-day rural population, the surrounding concentration of objects of sacral topography, and the well-known practice of 'assimilation' of sanctuaries of past epochs in the course of the introduction of Christianity make it possible to see lakes called sacred and lakes related to the story of a sunken church as loci of mythological and ritual importance of pre-Christian times. The issue of sanctuaries that were once situated on the shores of these lakes should be clarified on the basis of complex field studies.

4. Most of the above-mentioned lakes called святое, свяцец, ичаркавищча, иаркоўнае, вочка, бяздоннае and considered to be sites of vanished churches are quite prominent against the background of Baltic hydronyms recorded in the Dvina region. The origin of

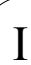

NATURAL HOLY PLACES IN ARCHAEOLOGY AND FOLKLORE IN THE BALTIC SEA REGION 
these lakes can be interpreted as Slavonic. The extraordinarily large accumulation of sacred lakes in the Polotsk region (a major religious centre in Eastern Europe in the 11th and 12th centuries) probably attests to the baptism of rural communities in the areas where the concentration of lakes was the highest. Most likely, Slavic groups in the population became the first neophytes. At this point, Vladimir Toropov's remark about the Slavic concept of sacrality is very important: anything that entered the field of sacrality would actually become sacred (Toporov 1995, p.489). It should be noted that in the locations with the largest number of sacred lakes, the largest number of sacred springs has been recorded too. Springs constitute a subject for separate research.

\section{References}

\section{Abbreviations}

AGFF - Archiu gistoryka-filalagichnaga fakulteta Polackaga dziarzaunaga universiteta

SET - Archiu Studenckaga etnagrafichnaga tavarystva $u$ Minske.

\section{Literature}

ANIKIEVICH, K., 1907. Sennenskij uezd Mogiliovskoj gub. Mogiliov: Gub. tip.

BELOVA, O., 2004. Krug. In: N. I. TOLSTOI, ed. Slavianskie drevnosti, 3. Moskva: Mezhdunarodnye otnoshenija, 11-12.

DUCHYC, L., 1993. Archealagichnyja pomniki u nazvach, veravanniakh i padanniakh belarusau. Minsk: Navuka i technika.

ZAJKOVSKIJ, E., 2006. Predanija o jazycheskich kul'tovych pamiatnikach Belarusi i archeologija. Kulturas krustpunkti, 3, 163-181.

KUZA, A., SOLOVJOV, G., 1972. Jazycheskoje sviacilische v zemle radimichej. Sovetskaja archeologija, 1, 42-45.

LEGENDY, 2005. Legendy i padanni. Minsk: Belaruskaja navuka.

PANCHENKO, A., 1998. Issledovanija v oblasti narodnogo pravoslavija. Sankt- Peterburg: Aliteja.

RUSANOVA, I., TIMOSCHCHUK B., 1993. Jazycheskie sviacilischcha drevnich slavian. Moskva: ARCHE.

SALAVEJ, L., 2006. Khram, shto pravaliusia. In: S. SAN'KO, ed. Belaruskaja mifalogija. Minsk: Polymia, 535-536.

SHTYCHAU, G., 1993. Kryvichy: pa mater'jalach raskopak kurganou u Paunochnaj Belarusi. Minsk: Navuka i technika.

TOPOROV, V., 1995. Sviatos'c' i sviatyje v russkoj duchovnoj kul'ture. Vol. 1. Moskva: Gnozis.

Received: ... Revised: ... Accepted: ...

Uladzimer Lobach

quadra@tut.by

\section{ŠVENTIEJI PADAUGUVOS \\ REGIONO EŽERAI (ŠIAURĖS \\ VAKARŲ BALTARUSIJA)}

\section{Uladzimer Lobach}

\section{Santrauka}

Šiaurès vakarų Baltarusijoje, Padauguvos regione, esančių šventų ežerų tyrinėjimai, jų kartografavimas ir tautosakos šaltinių analizè leidžia išsakyti prielaidą, kad padavimai apie prasmegusią bažnyčią, susiję su minèto regiono vandens telkiniais, atspindi Polocko kunigaikštystès christianizacijos procesą. Šventas ežeras galèjo būti vieta, kur krikštą prièmė konkrečios lokalinès bendruomenès nariai. Matyt, neatsitiktinai šventi ežerai yra išsidèstę ten, kur didžiausia X-XI a. Polocko krivičių pilkapių koncentracija. Tuo metu Polocko kunigaikštystès periferijoje, kur daugumą sudarè gyventojai baltai, padavimų apie ežerus neužfiksuota, arba jie tik pavieniai.

Šventų ežerų savybės, tokios kaip mažas jų plotas, apskrita forma, vaizdiniai apie nepaprastą vandenị ("miręs" ežero vanduo, arba turintis gydomujų savybių) rodo, kad šie vandens telkiniai sakralinės reikšmės turèjo dar iki krikščionybès įvedimo. 
